\title{
Metode Pendokumentasian Elektronik dalam Meningkatkan Kualitas Pelayanan Keperawatan
}

\author{
Sulastri ${ }^{1}$, Niken Yuniar Sari ${ }^{2}$ \\ ${ }^{1}$ Jurusan Keperawatan, Politeknik Kesehatan Tanjungkarang, Indonesia \\ ${ }^{2}$ Program Studi Ners, Sekolah Tinggi Kesehatan Mitra Lampung, Indonesia \\ Email: sulasdes@gmail.com
}

\begin{abstract}
Electronic Documentation Methods in Improving the Quality of Nursing Services. Nursing documentation is one of the most important functions for nurses in providing nursing care. The nursing process in the modern era is now a demand from various aspects for nurses. The current development is that nurses must carry out nursing processes based on nursing care standards. The use of electronic nursing documentation can always evolve in line with technological developments, this can increase client life expectancy and reduce errors in intervening with clients. This IT-based documentation system will help in meeting documentation standards, can improve the quality of documentation, facilitate decision making and provide information that is easy to access, can minimize the potential for loss or damage to development records, improve information exchange and coordination between nurses or other health teams, documentation can be easily audited, help improve the accuracy of client data, can access the progress of client health development and reduce maintenance costs so that it can improve the quality of care services.
\end{abstract}

Keywords: Computerization, Documentation, Nursing, Technology information

\begin{abstract}
Abstrak: Metode Pendokumentasian Elektronik dalam Meningkatkan Kualitas Pelayanan Keperawatan. Dokumentasi keperawatan merupakan salah satu fungsi yang paling penting bagi perawat dalam memberikan asuhan keperawatan. Proses keperawatan di era modern saat ini menjadi tuntutan dari berbagai aspek bagi para perawat. Perkembangan saat ini bahwa perawat harus melakukan proses keperawatan berdasarkan standar asuhan keperawatan. Penggunaan dokumentasi keperawatan secara elektronik dapat selalu berkembang sejalan dengan perkembangan teknologi, ini dapat meningkatkan harapan hidup klien dan mengurangi kesalahan dalam melakukan tindakan intervensi pada klien. Sistem dokumentasi yang berbasis IT ini akan membantu dalam memenuhi standar dokumentasi, dapat meningkatkan kualitas dokumentasi, memudahkan dalam pengambilan keputusan serta menyediakan informasi yang mudah di akses, dapat meminimalkan potensi kehilangan atau kerusakan catatan perkembangan, meningkatkan pertukaran informasi dan koordinasi antara perawat atau tim kesehatan lain, dokumentasi dapat mudah diaudit, membantu meningkatkan akurasi data klien, dapat mengakses kemajuan perkembangan kesehatan klien serta mengurangi biaya perawatansehingga dapat meningkatkan kualitas pelayanan perawatan.
\end{abstract}

Kata kunci: Komputerisasi, Dokumentasi, Keperawatan, Teknologi infomasi

Dokumentasi keperawatan merupakan bagian integral dari asuhan keperawatan, dokumentasi keperawatan merupakan salah satu fungsi yang paling penting dari perawat. Disini ditulis segala informasi tentang klien sehingga dapat memberikan asuhan keperawatan yang sesuai dengan kebutuhan klien. Melalui dokumentasi perawat dapat memutuskan tindakan yang tepat untuk klien.

Keakuratan suatu data data klien dalam proses keperawatan di era modern saat ini menjadi tuntutan dari berbagai aspek bagi para perawat, bermacam macam bentuk, upaya telah dilakukan selama bertahun-tahun untuk meningkatkan dokumentasi keperawatan, hal ini dilakukan dalam upaya untuk meningkatkan kualitas pelayanan perawatan klien (Paan et al, 2010). Sebuah keprihatinan bersama mengenai dokumentasi keperawatan adalah catatan mengenai pengkajian yang tidak aktual, intervensi, implementasi serta evaluasi keperawatan yang tidak konsisten dan tidak lengkap sehingga tidak memenuhi standar asuhan keperawatan.Dalam hal ini catatan keperawatan tidak mendukung sebagai informasi yang dapat 
dipertanggungjawabkan dalam hukum (Chand, 2014).

Perkembangan saat ini bahwa perawat harus melakukan proses keperawatan berdasarkan standar asuhan keperawatan. (Hickey et al, 2012). Smith et al (2005) mengatkan bahwa Ini tidak berjalan dengan baik dikarenakan dokumentasi keperawatan dilakukan secara manual, data direkam menggunakan tulisan atau direkam dalam bentuk grafik. Dan dokumentasi ini memungkinkan tidak terbaca oleh tim kesehatan lain, meskipun mungkin berisi informasi yang penting. Ini tidak dapat meningkatkan pertukaran informasi dan koordinasi baik antar perawat maupun tim kesehatan lainya.

Banyak data yang dikumpulkan secara berulang ulang dan mungkin tidak tepat. Pada tahun 1988 asuhan keperawatan dilaporkan mencapai lebih dari seperempat dari biaya rumah sakit. Sistem dokumentasi yang berbasis IT ini akan membantu dalam memenuhi standar dokumentasi, dapat meringankan beban kerja perawat dan dapat meningkatkan kualitas dokumentasi dengan laporan yang dihasilkan akan terbaca secara otomatis. Laporan juga dapat memberikan data yang segera tersedia untuk mengetahui hari rawat klien, mengurangi biaya perawatan, audit, kontrol layanan kesehatan (Nokes et al, 2012).

Catatan keperawatan berbasis elektronik diharapkan dapat meningkatkan kualitas perawatan yang diberikan kepada pasien yang dirawat di rumah sakit. Bagi perawat, penggunaan sumber dokumentasi elektronik menjadi sangat relevan karena di sinilah perawat memperoleh dan menuangkan sebanyak mungkin informasi pasien yang sesuai kebutuhan. Belum banyak tinjauan integratif literatur yang ada berkaitan dengan penelitian hubungan antara dokumentasi keperawatan elektronik dan kualitas perawatan yang diberikan kepada pasien rawat inap. Perlu ditinjau lebih dalam mengenai literatur empiris agar metode ini mudah diterapkan dilapangan. Sampai saat ini, penggunaan dokumentasi keperawatan elektronik untuk meningkatkan hasil pasien masih belum perlu diaplikasikan untuk selanjutnya dilakukan penelitian. Penelitian dilakukan untuk mengetahui seberapa efektif interaksi sehari-hari antara perawat dan dokumentasi keperawatan elektronik untuk penyediaan perawatan berkualitas bagi pasien yang dirawat di rumah sakit. Mayoritas unit perawatan rumah sakit AS saat ini menggunakan dokumentasi keperawatan berbasis kertas untuk bertukar informasi pasien dengan perawatan berkualitas. (Kelley TF, Brandon DH, \& Docherty SL, 2011).

Catatan keperawatan elektronik digunakan dalam lembaga perawatan kesehatan untuk meningkatkan kualitas dan keamanan perawatan pasien. Metode ini dianggap penting dan direkomendasikan oleh penyedia layanan kesehatan di lembaga perawatan kesehatan untuk digunakan. Namun, ada tantangan yang terkait dengan dalam penerapan catatan keperawatan elektronik, seperti perlu fasilitas yang memadai dan kemampuan sumber daya manusia yang mumpuni untuk melakukannya. Namun demikian tantangan-tantangan harus dicarikan solusinya, melihat dampaknya untuk meningkatkan efisiensi, dan sistem ini memiliki manfaat. Dalam organisasi layanan kesehatan, dokter dan perawat adalah penyedia layanan utama yang mendapat manfaat secara langsung atau tidak langsung dari sistem pendokumentasian elektronik selain dari pasien. Para ahli kesehatan telah mengakui bahwa kemampuan perawat dan dokter untuk memanfaatkan pendokumentasian elektronik secara signifikan sangat efektif dalam perawatan pasien dan meningkatkan kesejahteraan pasien, mengurangi biaya untuk pelatihan dan mengurangi pengeluaran perawatan kesehatan, Namun, perawat memerlukan keterampilan dan pengetahuan untuk menggunakan pendokumentasian elektronik secara efektif, mereka mendapatkan pengetahuan melalui pelatihan dan pelatihan kerja (Powell-Cope, Nelson \& Patterson 2008, 50 dalam Kamau, Nancy, 2015).

Saat ini teknologi telah berkembang pesat, begitu pula dengan teknologi yang dikembangkan untuk dapat mendukung kinerja keperawatan dalam hal dokumentasi yang berbentuk sistem dokumentasi keperawatan secara elektronik. Aplikasi ini berbasis teknologi IT yang akan mendukung dalam pencatatan serta pendokumentasian keperawatan terhadap suatu kasus pada klien. Seperti halnya negara-negara eropa yang telah megembangkan teknologi untuk meningkatkan sistem pendokumentasian yang merupakan metode sistematis. Dokumentasi keperawatan yang telah ditujukan untuk meningkatkan catatan klien dan mempertahankan kualitas asuhan keperawatan (Lovlien et al, 2007).

\section{KAJIAN LITERATUR}

Dokumentasi merupakan segala sesuatu yang tercetak atau tertulis yang dapat dijadikan 
sebagai catatan tentang bukti bagi individu yang berwenang (Potter, 2005).

Penggunaan dokumentasi keperawatan secara elektronik dapat selalu berkembang sejalan dengan perkembangan teknologi, sehingga dapat meningkatkan harapan hidup klien dan mengurangi resiko kesalahan dalam melakukan tindakan kepada klien. Dokumentasi keperawatan memudahkan dalam pengambilan keputusan serta menyediakan informasi yang mudah di akses, dapat meminimalkan potensi kehilangan atau kerusakan catatan perkembangan klien, meningkatkan pertukaran informasi dan koordinasi antara perawat atau tim kesehatan lain, dokumentasi dapat mudah diaudit, membantu meningkatkan keakuratan data klien, dapat mengakses kemajuan perkembangan kesehatan klien serta mengurangi biaya perawatan (Kelley et al, 2011).

Dokumentasikan keperawatan secara elektronik ini menggunakan sistem keamanan, kerahasiaan serta hak akses. Memastikan privasi dan keamanan informasi klien dengan menekankan pada penggunaan akses melaui password, akses informasi diberikan untuk orang yang berwenang saja (Blair \&Barbara Smith, 2012).

Catatan sistem pendokumentasian elektronik berisi masalah, demografi pasien, obat-obatan, dan catatan kemajuan, simbol vital, riwayat kesehatan masa lalu, data laboratorium, imunisasi, dan laporan radiologi. Beberapa manfaat penting dalam pendokumentasian elektronik termasuk kemampuan untuk dengan mudah mengakses dokumen yang terkomputerisasi dan meninggalkan pencatatan manual yang sangat mungkin sulit untuk dibaca atau adanya kesalahpahaman karena penulisan yang tidak jelas. Hal ini dapat menimbulkan kesalahan dalam rekam medis. Sistem pendokumentasian elektronikdiharapkan dapat meningkatkan nilai perawatan dan meminimalkan biaya pada tingkat sistem penyediaan layanan kesehatan. Tiga fungsi utama ini termasuk pertukaran informasi kesehatan, instrumen penunjang pengambilan keputusan klinis, dan advis dokter yang terkomputerisasi. Pendokumentasian elektronik yang menggunakan instrumen dukungan pengambilan keputusan medis secara empiris dikaitkan dengan peningkatan kepatuhan terhadap strategi klinis berbasis bukti dan perawatan yang efisien. Terlepas dari tujuan ideal penyedia layanan kesehatan, beberapa faktor dapat memberikan hasil dalam pengalaman pasien yang tidak berpegang pada prinsip panduan praktik terbaik. Namun, perawat berada dalam posisi yang lebih baik dengan menggunakan sistem ini sehingga dapat menawarkan layanan yang efektif (Menachemi \& Taleah 2011, dalam Kamau, Nancy, 2015).

Setiap perawat membawa tablet komputer untuk melakukan dokumentasi keperawatan pada klien, dengan perawatan yang tepat dan konfirmasi intervensi keperawatan, pemeriksaan obat-obatan, memberikan keseragaman dalam pendokumentasian dan berbagi informasi dengan tim medis lainya dengan dukungan dokumentasi elektronik keperawatan.

Data yang terkumpul direstrukturisasi untuk menghasilkan print-out dalam bentuk situasi, baground, pengkajian, rekomendasi (SBAR). Dokumen dapat dibaca pada satu halaman dan menghasilkan laporan secara otomatis dan dapat di access secara bersama semua tim kesehatan.Termasuk diagnosa pasien, obat-obatan , prognosis, aktivitas yang diizinkan, alergi, keterbatasan fungsional, status mental, persyaratan gizi, keamanan langkah-langkah, frekwensi dan durasi kunjungan untuk layanan keperawatan yang tepat. Implementasi dan evaluasi dapat diakses selama 12 jam (American Hospital Association dan Pricewaterhouse Coopers, 2001).

\section{PEMBAHASAN}

Dokumentasi adalah rekaman tertulis dan hukum dari intervensi yang menyangkut pasien dan itu mencakup serangkaian proses. Dokumentasi dibuat dengan catatan pribadi pasien, yang merupakan basis informasi tentang situasi kesehatannya. Pentingnya dokumentasi keperawatan adalah neuralgik, asalkan tanpa itu, tidak akan ada intervensi keperawatan kualitatif lengkap dan bahkan tidak ada perawatan yang efektif untuk pasien.

Dalam tujuan dokumentasi keperawatan termasuk penelitian tentang perawatan yang lebih efektif dari masalah yang sudah terdeteksi, pemrograman perawatan melalui organisasi dan modifikasi rencana perawatan pasien dan komunikasi yang lebih langsung antara para profesional dari sistem kesehatan, yang berkolaborasi dalam perawatan pasien. Metode dokumentasi banyak dan di antara yang paling mendasar adalah metode yang diarahkan pada sumber atau masalah, sistem masalah-intervensievaluasi, registrasi terfokus, diagram fokus, registrasi dengan pengecualian, file elektronik dan rumah dokumentasi.

File pasien harus menggambarkan situasinya saat ini dan mencerminkan 
keseluruhan proses keperawatan. Terlepas dari sistem dokumentasi yang digunakan oleh suatu institusi, perawat mendaftar secara terus-menerus berbagai bukti aktivitas keperawatan, selama durasi manfaat perawatan.

Pendokumentasian elektronik merupakan sistem pencatatan berbasis komputer yeng merekam aktifitas yang dilakukan oleh perawat dalam aktivitas keperawatan, yaitu pendokumentasian asuhan keperawatan. Catatan yang ditulis menginformasikan semua kunjungan perawat dalam bentuk catatan ringkasan singkat dari kebutuhan perawatan pasien dan intervensi yang telah diterapkan.

Diperkirakan bahwa pada tahun 200, sebagian besar fasilitas kesehatan akan menerapkan beberapa jenis pendokumentasian elektronik dan sistem dokumentasi elektronik. Pada tahun 2003, Tommy G. Thompson, Sekretaris Departemen Kesehatan dan Layanan Kemanusiaan, meminta dua organisasi bergengsi, Institut Kedokteran dan Kesehatan Level 7, untuk membentuk gugus tugas nasional untuk merancang standar untuk pendokumentasian elektronik. Gugus tugas telah mengusulkan model dengan standar untuk digunakan dalam beberapa proyek percontohan pendokumentasian elektronik. Sampai saat ini, model pendokumentasian elektronik telah berdampak luas pada seluruh komunitas layanan kesehatan, mulai dari perusahaan besar hingga praktik individu, dengan banyak negara membentuk dewan penasihat untuk menyusun strategi bagaimana pendokumentasian elektronik dapat diterapkan di seluruh negara bagian. Melalui Sistem Informasi dan Manajemen Kesehatan telah dikembangkan model definisi yang merinci delapan atribut dan persyaratan penting untuk pendokumentasian elektronik, dari kebutuhan untuk catatan aman yang dapat diakses secara waktu nyata hingga catatan yang dapat membantu mendukung uji klinis. Semua agen layanan kesehatan diharapkan memiliki pendokumentasian elektronik dalam waktu dekat untuk memastikan keamanan dan dokumentasi perawatan yang lebih baik. Untuk banyak alasan, perpindahan ke catatan layanan kesehatan tanpa kertas adalah usaha yang menakutkan dan mahal bagi lembaga layanan kesehatan, dan tidak semua orang antusias dengan penggunaan pendokumentasian elektronik. Dengan demikian, tingkat adopsi sangat bervariasi dari satu daerah ke daerah lain. Banyak masalah yang dihadapi dalam implementasi pendokumentasian elektronik bersifat organisasi dan perilaku, dan dapat dikaitkan dengan sikap terhadap penggunaan teknologi elektronik atau kegagalan pelaksana untuk mencari masukan dari pengguna potensial (Moody, Elaine Slocumb, Bruce Berg, \& Donna Jackson, 2004).

Dokumentasi ini melaporkan kondisi aktual pasien sehingga mempercepat tim kesehatan dalam mengambil keputusan yang tepat dalam memberikan perawatan pasien dan menetapkan prioritas serta memutuskan perawatan yang sesuai dengan intervensi. Selanjutnya data yang terkumpul disimpan dalam database sebagai bukti tertulis tentang kemajuan pasien.

Komite Praktik Keperawatan merekomendasikan konsistensi dalam prosedur perawatan berbasis bukti, yang terdiri dari datapasien dan data-data rencana strategi, di dalam dan pada akhirnya di seluruh situasi perawatan. Penilaian kualitasperawatan yang sesuai hanya dapat disiapkan ketika proses dan komoditas yang konsisten berlaku (Lavin, et al 2015, dalam Kamau, Nancy, 2015). Jika perawat atau ahli perawat menggunakan sumber daya mereka dan tidak mampu memanfaatkan secara maksimal, seperti tidak mampu menerapkan sesuai dengan kemampuan yang seharusnya dimiliki oleh perawat yang mampu menggunakan pendokumentasian elektronik. Dengan demikian perawat akan merasa nyaman menjalankan pekerjaannya.

Menurut Arevalo (2005, dalam Kamau, Nancy, 2015) tugas-tugas penjadwalan yang tidak tepat dan tidak efisien dalam penyediaan layanan kesehatan adalah banyak kesulitan dalam memberikan perawatan klien yang berkualitas dan mengelola biaya medis, seperti halnyakekurangan tenaga kerja. Penulis lebih lanjut menunjukkan bahwa salah satu cara untuk mencapai efisiensi adalah dengan mencegah tidak konsistennya dalam penyediaan prosedurlayanan kesehatan sehingga dapat memanfaatkan dengan baik tenaga kerja yang tersedia. Sebagian besar lembaga kesehatan sekarang memperkirakan staf perawat mempertimbangkan rata-ratakebutuhan pasien. Namun, lambang permintaan menimbulkan stres bagi perawat dan berdampak pada kualitas perawatan. Demikian pula, pernyataan American Nurses Association (ANA) menyatakan bahwa meningkatkan pengaturan kerja pada akhirnya tergantung pada fase kemamuan perawat.

\section{SIMPULAN}

Dokumentasi keperawatan yang berbasis teknologi IT sangat diperlukan di era modern saat ini disamping dapat memberikan keakuratan data 
kepada klien serta perencanaan untuk megahasilkan kualitas dan kinerja perawat dalam melakukan asuhan keperawatan yang baik. Sebagai pelaksana pelayanan kesehatan, rumah sakit juga sangat terbantu dengan adanya sistem dokumentasi keperawatan secara elektronik karena dapat menyediakan akses yang cepat dalam memberikan informasi, meminimalkan potensi kehilangan atau informasi yang rusak, menekan anggaran biaya yang dikeluarkan. Dapat mengurangi resiko kesalahan dalam melakukan intervensi, membantu dalam memenuhi pertanggungjawaban dokumentasi melalui akurasi informasi dan data pasien, memudahkan data epidemiologi, meningkatkan komunikasi dalam pertukaran informasi serta koordinasi diantara perawat dan anggota tim kesehatan lainya, meningkatkan keselamatan pasien dengan mengurangi kesalahan medis (John et al, 2016).

\section{SARAN}

Memberikan masukan kepada pelaksana pelayanan kesehatan untuk dapat mendokumentasikan asuhan keperawatan dengan sistem berbasis teknologiterutama di Rumah

\section{DAFTAR PUSTAKA}

American Hospital Association. 2001. Patient or paper work. The regulatory burden facing America's

Hospital. http:/tinyurl.com/cfnmvqc.

Blair, W., \& Barbara Smith. 2012. Nursing Documentation: Framewor and Barriers. Contemporary Nurse, 41(2), 160-168.

Chand, S. 2014. Electronic nursing documentation. International Journal of Information Dissemination and Technology, $\quad 4(4), \quad 328$. http://search.proquest.com/openview/d6d5 5f2afd6a05546fe10097d559980a/1?pqorigsite $=$ gscholar.

Hickey, A., Gleeson, M., \& Kellett, J. 2012. READS: the rapid electronic assessment documentation system. British Journal of Nursing, 21(22), 1333-1339.

John, S. K., \& Bhattacharya, C. 2016. Documentation guidelines based on expectation of documentation helps accurate documentation among nurses in psychiatric settings. Asian Journal of Nursing Education and Research,6(2), 260.
Sakit jiwa dimana klien gangguan jiwa yang sudah kembali ke rumah sering mengalami kekambuhan dan harus kembali untuk di rawat di rumah sakit. Dengan mrnggunakan sistem ini rekaman riwayat penyakit klien sebelumnya akan lebih mudah di akses. Rumah sakit dapat menunjang kualitas pelayanan yang bertujuan terhadap kepuasan klien.

Pendokumentasian asuahan keperawatan berbasis teknologi ini juga dapat memacu kemajuan perawat, tenaga kesehatan lain, Rumah sakit memiliki daya saing yang tinggi karena dapat mengurangi resiko kesalahan asuhan keperawatan sehingga meningkatkan kualitas keselamatan klien.

Sistem dokumentasi keperawatan secara elektronik merupakan sistem yang baikjika diterapkan di Indonesia karena lebih efisien, banyak tindakan keperwatan yang membutuhkan waktu yang lama, ini tentunya mengurangi waktu perawat dalam menulis dan membuat perawat lebih caring terhadap klien namun ini menjadi tantangan bagi perawat dalam memenuhi kebutuhan klien berbagai hambatan yang dapat dialami seperti sumber daya manusia, perlunya pelatihan dan sistem pelayanan dirumah sakit dalam penggunaan sistem informasi manajemen.

Kamau, Nancy. 2015. Electronic Health Documentation and Its Impact on Nurses Routine Practices Literature Review. https://www.theseus.fi/bitstream/handle/10 024/104801/Nancy\%20Kamau\%20PDF.pd $\mathrm{f}$ ? sequence $=1$.

Kelley TF, Brandon DH, \& Docherty SL. 2011. Electronic Nursing Documentation as a Strategy to Improve Quality of Patient Care. Journal of Nursing Scholarship, 43(2):154-62.

Lovlien, C. a, Johansen, M., Timm, S., Eversman, S., Gusa, D., \& Twedell, D. 2007. Improving program documentation quality through the application of continuous improvement processes. Journal of Continuing Education in Nursing, 38, 271-276.

Moody, L. E., Slocumb, E., Berg, B., \& Jackson, D. 2004. Electronic health records documentation in nursing: nurses' perceptions, attitudes, and preferences. CIN: Computers, Informatics, Nursing, 22(6), 337-344. 
Nokes, Kathleen M., Aponte, Judith, Nickitas, Donna M., Mahon, Pamela Y., Rodgers, Betsy, Reyes, Nancy, . . . Dornbaum, Martin. 2012. Teaching Home Care Electronic Documentation Skills to Undergraduate Nursing Students. Nursing Education Perspectives, 33(2), 111-115.

Potter. 2005. Fundamentals Of Nursing: Concepts Process And Practice. California: Addison Wesley.
Smith, K., Smith, V., Krugman, M., \& Oman, K. 2005. Evaluating the impact of computerized clinical documentation. Computers, Informatics, Nursing: CIN, 23(3), $132-138$. http://doi.org/10.1097/00024665200505000-00008. 